\title{
Non-covalent Multivalent Assembly of Jun Peptides on a Leucine Zipper Dendrimer Displaying Fos Peptides
}

Min Zhou and Indraneel Ghosh*

Department of Chemistry, University of Arizona, Tucson, AZ 85721

\section{Supplementary Material}

\section{Materials and Methods}

\section{General Materials:}

All amino acid derivatives, HOBT, BOP and resins used for peptide synthesis were purchased from Novabiochem. All other chemicals and reagents were from Aldrich. HPLC columns were from Vydac.

\section{Peptide Synthesis and Purification:}

The peptide-Fos and peptide-Jun were synthesized by solid-phase peptide synthesis using standard Fluorenylmethoxycarbonyl (Fmoc) strategy starting with Rink Amide resin.

Sequences:

PFOS: $\mathrm{NH}_{2}$-CGSGSLTDTLQAETDQLEDEKSALQTEIANLLKEKEKLEFILAA-CONH 2

PJun: $\mathrm{NH}_{2}$-RIARLEEKVKTLKAQNSELASTANMLREQVAQLKQKVAASGSGCG-CONH

PJun-HC: Coumarin-GGRIARLEEKVKTLKAQNSELASTANMLREQVAQLKQKVAASGSGCG-CONH ${ }_{2}$

The final peptides (PJun) were cleaved from the resin and all protecting groups were removed by the general TFA cleavage (Peptide resin $1 \mathrm{~g}$ was treated with $10 \mathrm{ml}$ cleavage cocktail $(81.5 \%$ TFA, 5\% water, 5\% thioanisole, 5\% Phenol, 2.5\% ethanedithiol and 1\% triisopropylsilane) for 90 minutes at room temperature. The solution was filtered and precipitated by transferring into a centrifuge tube containing $50 \mathrm{ml}$ pre-cooled ether. After centrifugation and $3 \times$ washes with fresh ether, the white solid was collected and lyophilized to yield $0.4 \mathrm{~g}$ crude peptide. The crude peptide was purified by reverse-phase HPLC (Varian) using a C18 column (Vydac). Peptides were purified with a linear gradient of $20 \%$ to $80 \%$ acetonitrile containing $0.1 \%$ TFA at a flow rate of $8 \mathrm{ml} / \mathrm{min}$, for 60 minutes. $\sim 130 \mathrm{mg}$ pure peptide was obtained after purification.

Mass Spectroscopy (MALDI) of the two peptides:

The $\mathrm{MH}^{+}$calculated for PFos is 4792.45; found: 4792.63

The $\mathrm{MH}^{+}$calculated for PJun is 4811.61 ; found 4813.25

The $\mathrm{MH}^{+}$calculated for PJun-HC is 5113.85 ; found 5114.16 


\section{Amino Acid Analysis}

PFos: Asx (3) 3.29, Glx (10) 10.19, Ser (3) 2.60, Gly (2) 2.37, Thr (4) 4.35, Ala (5) 4.77, Ile (2) 1.37, Leu (8) 7.55, Phe (1) 0.77, Lys (4) 4.52.

PJun: Asx (2) 2.24, Glx (8) 8.50, Ser (4) 4.28, Gly (3) 3.32, Arg (3) 2.56, Thr (2) 1.90, Ala (7)

6.43, Val (3) 3.31, Met (1) 0.74, Ile (1) 0.96, Leu (5) 4.70, Lys (5) 4.90.

The results are consistent with the desired primary sequences.

\section{Synthesis of 7-Hydroxycoumarin-3-carboxylic acid (1)}

A mixture of $2.4 \mathrm{~g}$ 2,4-dihydroxybenzaldehyde $(20 \mathrm{mmol}), 2.89 \mathrm{~g}$ Meldrum's acid (20 mmol), piperidinium $(0.4 \mathrm{mmol})$ and ethanol were stirred at room temperature for 20 minutes, and then refluxed for 2 hours. The reaction mixture was allowed to cool down to room temperature, followed by chilling in an ice bath for 30 minutes. The crystallized product was filtered, washed three times with ethanol, and dried in vacuum. Finally, $\sim 3 g$ yellow product (1) was collected.

Reference: Song, A; Wang, X; Lam, K. S.; Tetra. Lett., 2003, 44, 1755-8

Synthesis of Succinimido 3-Maleimidopropanoate (2).

$\beta$-Alanine $(0.91 \mathrm{~g}, 10 \mathrm{mmol})$ was added to a solution of maleic anhydride $(1.0 \mathrm{~g}, 10 \mathrm{mmol})$ in $12 \mathrm{ml}$ DMF, stirred for 2 hours at room temperature. When the entire solid was dissolved, an ice bath was used to decrease the temperature to $0{ }^{\circ} \mathrm{C}$. N-Hydroxysuccinimide $(1.44 \mathrm{~g}, 12.5 \mathrm{mmol})$ was added into the solution followed by DCC (4.12g, 20mmol). After 5-10 minutes, ice bath was removed and the reaction was kept at room temperature overnight, and white precipitate was obtained. The precipitate was washed with $60 \mathrm{ml}$ water and $60 \mathrm{ml}$ dichloromethane. The organic layer was washed with $40 \mathrm{ml}$ water followed by $3 \mathrm{X} 20 \mathrm{ml} 5 \% \mathrm{NaHCO}_{3}$ and finally, saturated $\mathrm{NaCl}$ solution. The organic layer was dried with $\mathrm{Na}_{2} \mathrm{SO}_{4}$ and the dichloromethane removed under reduced pressure. $1.6 \mathrm{~g}$ solid $(60 \%$ yield $)$ was obtained.

Reference: Nicholas J. Ede, et al., Bioconjugate Chem., 1994, 5, 373-8

\section{Synthesis of NHS ester of PAMAM dendrimer (Generation 0) (3).}

$0.5 \mathrm{~g}$ of $20 \% \mathrm{w} / \mathrm{w}$ in methanol $(0.07 \mathrm{mmol})$ PAMAM dendrimer (Aldrich) was added into a round-bottom flask and methanol was removed under reduced pressure. 1ml DMSO was added into the flask to dissolve the dendrimer. $0.2 \mathrm{~g}$ of (2) $(0.75 \mathrm{mmol})$ was dissolved in $1 \mathrm{ml}$ DMSO followed by $0.1 \mathrm{~g}(0.78 \mathrm{mmol})$ Diisopropylethylamine to make the activated ester. After 2 minutes, the activated ester was added into the flask which contained the dendrimer solution, and the flask was kept shaking at room temperature for 30 minutes. The red solution was acidified by acetic acid and purified by reverse-phase HPLC by a C18 column. $22 \mathrm{mg}$ of pure product was obtained. ESI analysis verified the molecular weight and proton NMR was used to verify the structure and purity ( $>95 \%)$ of the product.

Mass Spectroscopy (ESI) calculated for compound (2) is 1121.16; Found: 1121.3.

${ }^{1} \mathrm{H}$ NMR (DMSO): $\delta 2.3(\mathrm{t}, 8 \mathrm{H}, \mathrm{J}=7.5 \mathrm{~Hz}), 2.48(\mathrm{~m}, 12 \mathrm{H}), 3.04(\mathrm{~m}, 24 \mathrm{H}), 3.58(\mathrm{t}, 8 \mathrm{H}, \mathrm{J}=7.5 \mathrm{~Hz})$, $6.99(\mathrm{~s}, 8 \mathrm{H}), 8.00(\mathrm{~s}, 4 \mathrm{H}), 8.12(\mathrm{~s}, 4 \mathrm{H})$. 


\section{Synthesis of Dendrimer $\left(\mathrm{D}_{0}-\mathrm{Fos}_{4}\right)(4)$}

$\mathbf{D}_{\mathbf{0}}$-Fos 4 was synthesized starting with $9.8 \mathrm{mg}$ of PFos dissolved in $5 \mathrm{~mL}$ buffer ( $0.1 \mathrm{M}$ Phosphate, $\mathrm{pH}=7.5) .0 .5 \mathrm{mg} 3(0.45 \mu \mathrm{mol})$ was added to the PFos solution. Argon was filled into the container to prevent disulfide bond formation. The reaction was kept overnight in a $37^{\circ} \mathrm{C}$ oven. The product (4) in the solution was purified by reverse-phase HPLC by a C18 column. Peptides were purified with a linear gradient of $20 \%$ to $80 \%$ acetonitrile containing $0.1 \%$ TFA at a flow rate of $8 \mathrm{ml} / \mathrm{min}$, for 60 minutes. $\sim 2 \mathrm{mg}$ of (4) (yield $\sim 24 \%$ ) was obtained and identified by MALDI (see below).

Reinjection of purified $\mathbf{D}_{\mathbf{0}}$-Fos 4 onto a $\mathrm{C} 18$ analytical column verified that it were greater than $95 \%$ pure.

Mass Spectroscopy (MALDI) of the $D_{0}$-Fos 4 :

MALDI calculated for $\mathrm{D}_{0}-\mathrm{Fos}_{4}\left(\mathrm{M}+\mathrm{H}^{+}\right)$is 20298.80 . Found: 20300.49

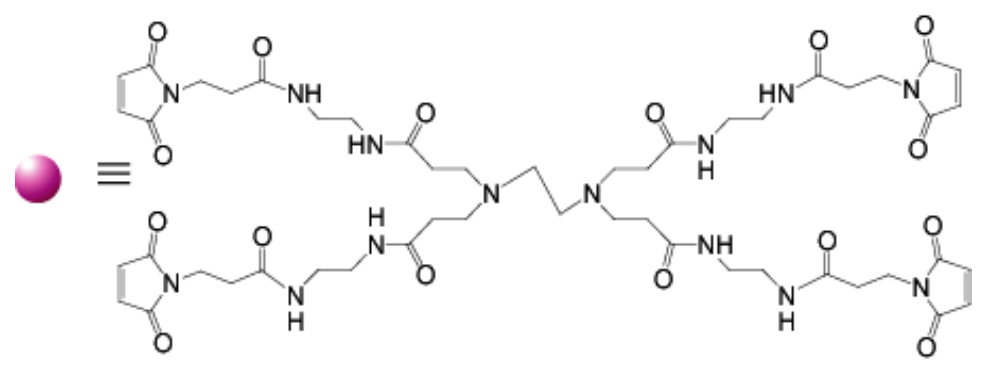

(3)

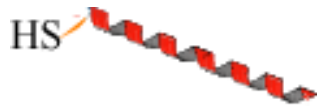

PFos: $\mathrm{NH}_{2}$-CGSGSLTDTLQAETDQLEDEKSALQTEIANLLKEKEKLEFILAA-CONH

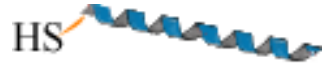

PJun: $\mathrm{NH}_{2}$-RIARLEEKVKTLKAQNSELASTANMLREQVAQLKQKVAASGSGCG-CONH

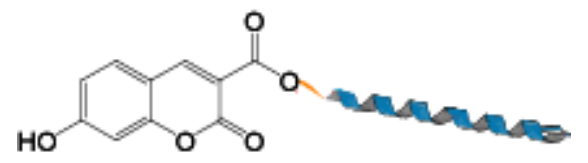

PJun-HC:

7-Hydroxycoumarin-GGRIARLEEKVKTLKAQNSELASTANMLREQVAQLKQKVAASGSGCG-CONH

Figure S1. Pink ball used in Fig.1 of manuscript represents the maleimide modified PAMAM generation 0 dendrimer. The peptide PFos and PJun and their sequence are also shown. 


\section{Circular Dichroism (CD) Spectroscopy}

CD spectra were recorded on an Aviv 62A-DS spectropolarimeter. All measurements reported were carried out in $\mathrm{pH} 7.0$ buffer ( $10 \mathrm{mM}$ phosphate, $100 \mathrm{mM} \mathrm{NaCl}, 1 \mathrm{mM}$ DTT), using a cuvette with a $1 \mathrm{~mm}$ pathlength.

Peptide concentrations were determined from the following method reported for quantitative measurement of protein thiol groups, and verified by amino-acid analysis.

Reagents

DTNB (Ellman's reagent), $10 \mathrm{mM}(4 \mathrm{mg} / \mathrm{ml})$ in absolute methanol

Tris base (20mM)-EDTA (50mM) buffer, $\mathrm{pH} 8.0$

Procedure

1. $130 \mu \mathrm{l}$ buffer $+15 \mu \mathrm{l}$ water $+5 \mu \mathrm{l}$ DNTB; absorbance B was measured at $412 \mathrm{~nm}$;

2. $130 \mu \mathrm{l}$ buffer $+15 \mu \mathrm{l}$ water $+5 \mu \mathrm{l}$ peptide stock solution; absorbance $\mathrm{C}$ was measured at $412 \mathrm{~nm}$;

3. $130 \mu \mathrm{l}$ buffer $+10 \mu 1$ water $+5 \mu 1 \mathrm{DTNB}+5 \mathrm{ml}$ peptide stock solution; absorbance A was measured at $412 \mathrm{~nm}$.

4. [peptide] $\mu \mathrm{M}=(\mathrm{A}-\mathrm{B}-\mathrm{C}) / 13600 \times(150 / 5) \times 10^{6}$

Reference: Hu, Miao-Lin, Methods in Enzymology, vol. 233, 381-5

Dendrimer-peptide hybrid concentrations were determined by amino-acid analysis.

All CD experiments were conducted at $25^{\circ} \mathrm{C}$ and under Argon to minimize peptide exposure to atmosphere in order to prevent disulfide bond formation. Ellmans test was performed before and after each experiment to insure the absence the disulfide bonds.

\section{Fluorescence Titration Utilizing the Gellman Assay}

Fluorescence spectra were recorded on PTI fluorimeter (814 photomultiplier detection system and LPS-220B lamp power supply). All measurements reported were carried out at $25^{\circ} \mathrm{C}$ and in a $\mathrm{pH} 7.0$ buffer $(10 \mathrm{mM}$ phosphate, $100 \mathrm{mM} \mathrm{NaCl}, 1 \mathrm{mM}$ DTT). In each experiment, the concentration of PJun-HC is $1.67 \mu \mathrm{M}$. The concentration of $\mathrm{D}_{0}-\mathrm{Fos}_{4}$ is from 0 to $5 \mu \mathrm{M}$ (which is from 0 to $20 \mu \mathrm{M}$ based on the PFos peptide). All the sample solutions were excited at $386 \mathrm{~nm}$ and the fluorescence emission was recorded from $400-600 \mathrm{~nm}$. The maximal emission is at 447 $\mathrm{nm}$. The following curves in Figure S2 individually represent the fluorescence emission of PJun$\mathrm{HC}\left(1.67 \mu \mathrm{M}\right.$, purple circle), $\mathrm{D}_{0}-\mathrm{Fos}_{4}(5 \mu \mathrm{M}$, green circle) and PFos $(20 \mu \mathrm{M}$, red circle). 


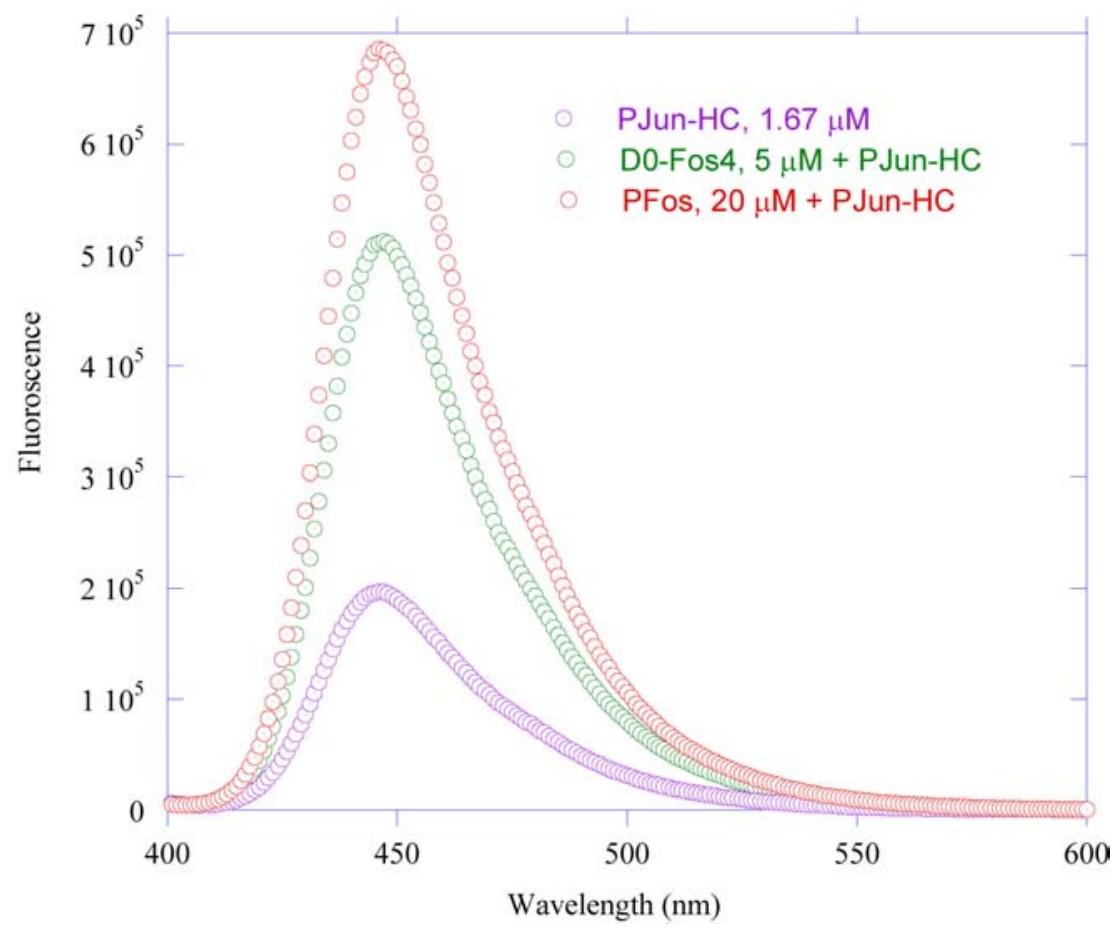

Figure S2. Fluorescence emission of PJun-HC $(1.67 \mu \mathrm{M}), \mathrm{D}_{0}-\mathrm{Fos}_{4}(5 \mu \mathrm{M})$ and Pfos $(20 \mu \mathrm{M})$. All samples were made in $\mathrm{pH} 7$ buffer $(10 \mathrm{mM}$ phosphate, $100 \mathrm{mM} \mathrm{NaCl}$, $1 \mathrm{mM}$ DTT), and excited at $386 \mathrm{~nm}$.

\section{Sedimentation Equilibrium Analysis}

Materials and Methods

All sedimentation experiments were conducted on Beckman Optima XL-1 ultracentrifuge. All samples were made in $\mathrm{pH} 7.0$ buffer with $10 \mathrm{mM}$ phosphate, $100 \mathrm{mM} \mathrm{NaCl}$ and $1 \mathrm{mM}$ DTT (buffer A), and the same buffer A was used for overnight dialysis. Concentrations were determined by a combination of amino acid analysis and DTNB assays. Equilibrium at each speed was judged to be complete when three consecutive scans taken at two-hour intervals were indistinguishable from each other. Typical equilibrium experiments at each speed were carried out over 24 hours at a particular rotor speed. Data was analyzed using SEDEQ 4.1 (Allen Minton, Laboratory of Biochemical Pharmacology, NIH).

\section{Result, Data Analysis and Discussion}

\section{1. $\mathrm{D}_{0}-\mathrm{Fos}_{4}$}

$40 \mu \mathrm{l}$ of $\mathrm{D}_{0}$-Fos 4 stock $(75.74 \mu \mathrm{M})$ was mixed with $210 \mu \mathrm{l}$ buffer and dialysis in $250 \mathrm{ml}$ of the same buffer overnight. In the data analysis (rotor speed $15 \mathrm{k} \mathrm{rpm}$ ), the molecular weight was unconstrained, and $20.2 \mathrm{kD}$ of molecular weight was obtained, which is consistent to the calculated molecular weight of $20.3 \mathrm{kD}$. 


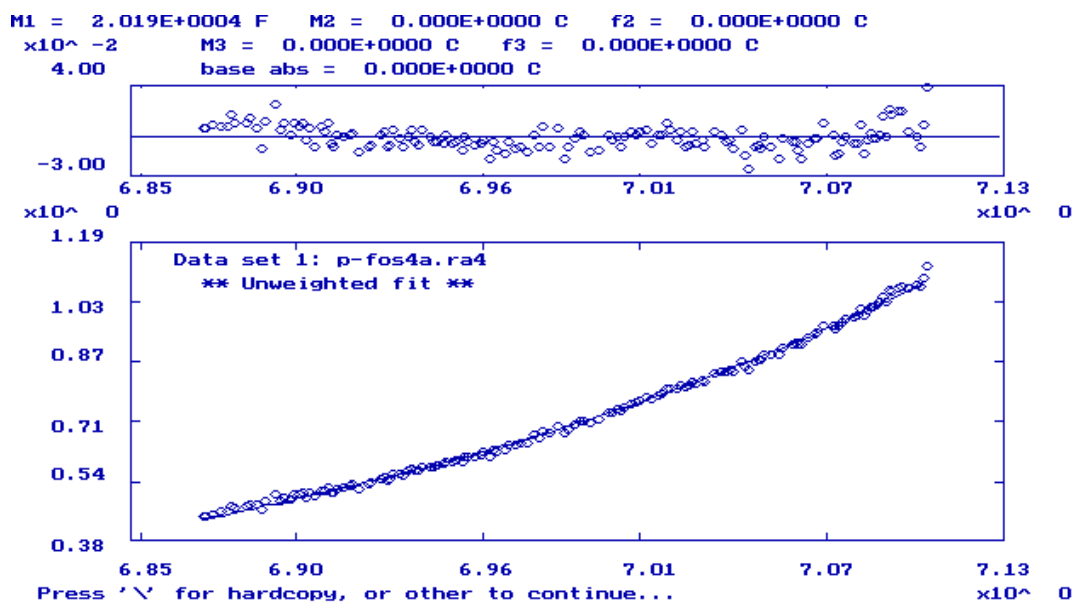

Figure S3. Sedimentation equilibrium result of $\mathrm{D}_{0}-\mathrm{Fos}_{4}$.

\section{PJun and PJun-HC}

$58 \mu \mathrm{M}, 29 \mu \mathrm{M}$ and $19.33 \mu \mathrm{M}$ of PJun in $\mathrm{pH} 7$ bufferA (after dialysis) were measured to calculate the $\mathrm{K}_{\mathrm{d}}$ of PJun (rotor speed 25k). The unconstrained fits resulted in fits to $4.8 \mathrm{kD}$ and $9.6 \mathrm{kD}$, following which in each experiment, the molecular weight were constrained to $4.8 \mathrm{kD}$ (monomer) and $9.6 \mathrm{kD}$ (dimer) of PJun. From the resulting ratios of monomer: dimer, the dissociation constant, $\mathrm{K}_{\mathrm{d}}$,was calculated as $45 \mu \mathrm{M}$. Similar experiments with PJun-HC also showed only monomers and dimers, which gave a $\mathrm{Kd}$ of $13 \mu \mathrm{M}$ in agreement with results reported ny Gellman and coworkers.
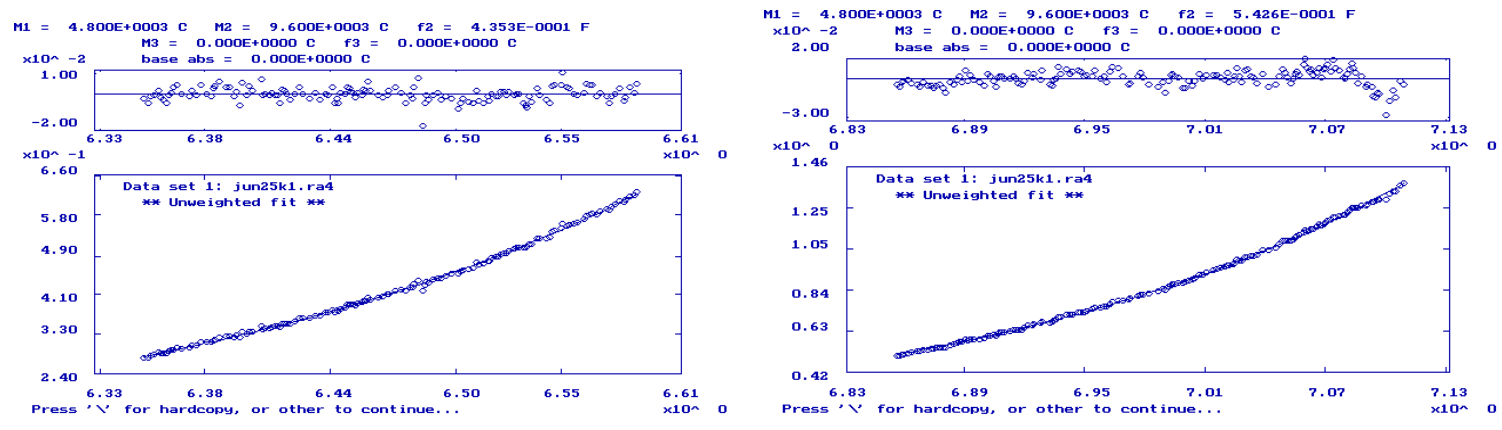

Figure S4. Sedimentation equilibrium result of PJun shown for concentrations of 29 and 58 ॥M

\section{3. $D_{0}-\mathrm{Fos}_{\mathbf{4}}+4$ equivalents of PJun}

$\mathrm{D}_{0}$ Fos $_{4}+4$ equivalents of PJun: $34.3 \mu \mathrm{D}_{0}$-Fos 4 stock solution $(75.7 \mu \mathrm{M})$ was mixed with $14.63 \mu \mathrm{l}$ PJun stock solution $(820 \mu \mathrm{M})$, and diluted to $300 \mu \mathrm{l}$ with $\mathrm{pH} 7.0$ bufferA. The sample was heated 10 minutes at $70 \sim 80{ }^{\circ} \mathrm{C}$ (over the $\mathrm{T}_{\mathrm{m}}$ ) and cooled to room temperature, 
filtered and dialyzed in $250 \mathrm{ml}$ of the same buffer overnight. The following table (S1) indicated all combinations of 3 components systems utilized to fit the equilibrium data (Figure S5.). We limited the fits to 3 components based on the principle of Ockam's Razor as the minimum number of variables that fit the data are judged to suitably explain the observed equilibrium and are in agreement with all other experimental data. The M.W. of $40 \mathrm{kD}$ indicated the complex that 1 molecule of $\mathrm{D}_{0}$-Fos 4 binds 4 molecules of PJun, and $30 \mathrm{kD}$ indicated the complex that 1 molecule of $\mathrm{D}_{0}$-Fos 4 binds 2 molecules of PJun. $20 \mathrm{kD}$ is the M.W. of $\mathrm{D}_{0}-\mathrm{Fos}_{4} .4 .8 \mathrm{kD}$ is the M.W. of PJun monomer and $9.6 \mathrm{kD}$ represents dimer.

\section{Table S1}

\begin{tabular}{|l|l|l|l|}
\hline Curve Fits & M.W. (kD) & Fraction & Conclusion \\
\hline 1 & 40 & 0 & No 40 kD and No PJun dimer makes this fit \\
& 30 & 0.764 & inconsistent. \\
& 4.8 & 0.236 & \\
\hline 2 & 40 & 0 & No 40 kD and no PJun monomer dimer make \\
& 30 & 0.709 & this fit inconsistent. \\
\hline 3 & 9.6 & 0.293 & \\
& 40 & 0.479 & No PJun monomer observed make this fit \\
& 9.6 & 0.525 & inconsistent. \\
\hline $\mathbf{4}$ & 4.8 & -0.004 & \\
& $\mathbf{3 0}$ & $\mathbf{0 . 7 3 9}$ & Most consistent result and in agreement with \\
& $\mathbf{9 . 6}$ & $\mathbf{0 . 1 2 7}$ & CD and fluorescence experiments \\
\hline 5 & $\mathbf{4 . 8}$ & $\mathbf{0 . 1 3 4}$ & \\
\hline 5 & 20 & & Meaningless as negative fractions obtained, and \\
& 9.6 & -0.06 & curve fits and residuals do not agree with the \\
& 4.8 & -0.11 & \\
\hline
\end{tabular}



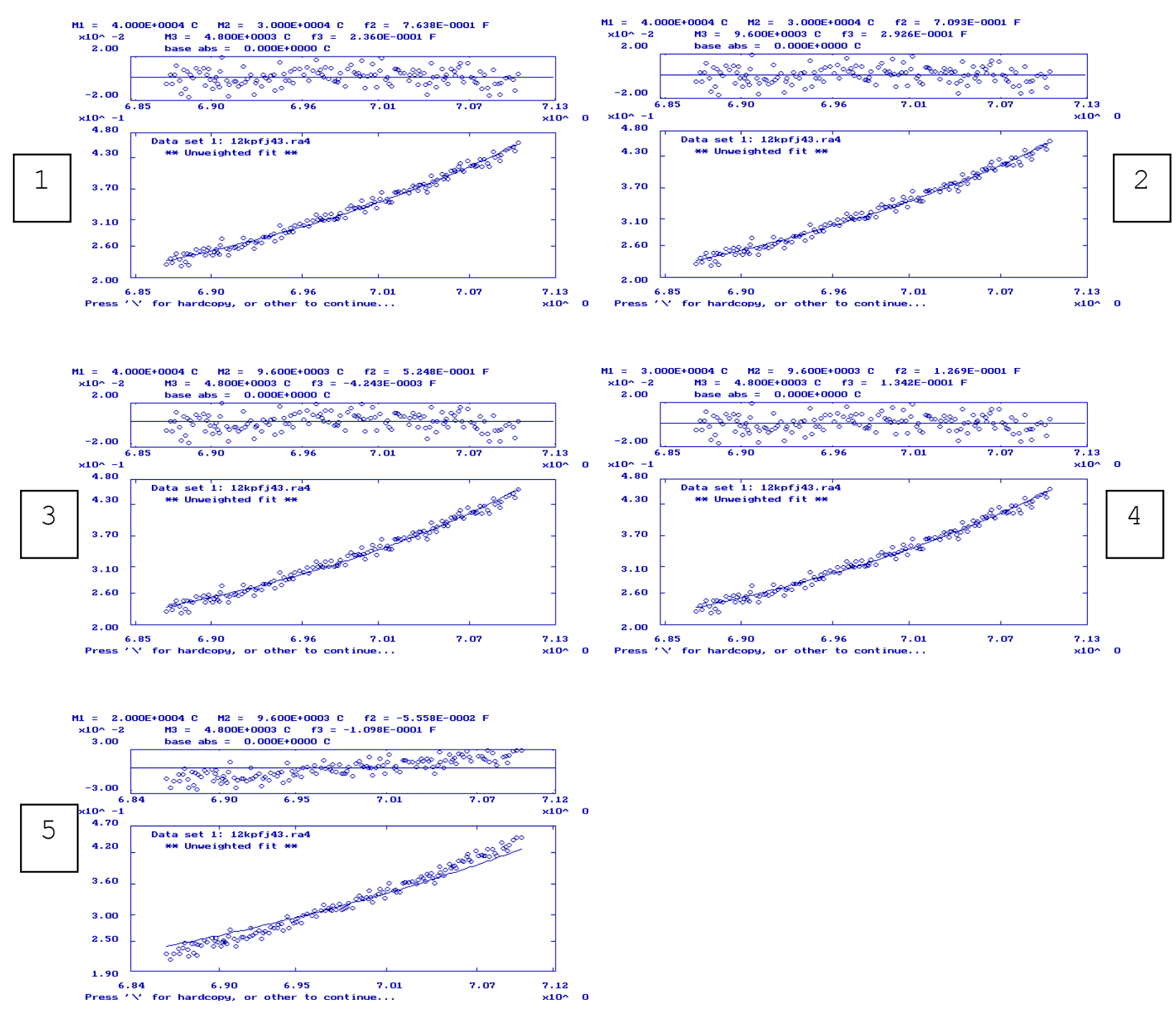

Figure S5. Sedimentation equilibrium data analysis of $\mathrm{D}_{0}-\mathrm{Fos}_{4}$ mixed with 4 fold of PFos. Fits are shown for $1-5$ as described in Table S1. 


\section{4. $D_{0}-F_{0 s}+8$ equivalents of PJun}

$\mathrm{D}_{0} \mathrm{Fos}_{4}+8$ equivalents of PJun: $42.2 \mu \mathrm{D}_{0}$-Fos 4 sock solution $(75.7 \mu \mathrm{M})$ was mixed with $34.5 \mu \mathrm{l}$ PJun stock solution $(743 \mu \mathrm{M})$, and diluted by $323 \mu \mathrm{l} \mathrm{pH} 7.0$ buffer to make $400 \mu \mathrm{l}$ solution. The sample was heated 10 minutes at $70 \sim 80{ }^{\circ} \mathrm{C}$, cooled to room temperature, filtered and dialyzed in $250 \mathrm{ml}$ of the same buffer overnight. The following table indicated all combinations of the 3 components system by which we tried to fit the data (see Figure S6).

\begin{tabular}{|c|c|c|c|}
\hline \multirow{2}{*}{\multicolumn{4}{|c|}{ Table S2 }} \\
\hline & & & \\
\hline FITS & M.W. (kD) & Fraction & Conclusion \\
\hline 1 & $\begin{array}{l}40 \\
30 \\
4.8\end{array}$ & $\begin{array}{l}0.243 \\
0.650 \\
0.107\end{array}$ & $\begin{array}{l}\text { Fraction of complex is too small based } \\
\text { upon known CD and fluorescence } \\
\text { experiments. The fractions for PJun } \\
\text { monomer/dimer ratio are not in } \\
\text { agreement. }\end{array}$ \\
\hline 2 & $\begin{array}{l}40 \\
30 \\
9.6\end{array}$ & $\begin{array}{l}0.230 \\
0.643 \\
0.127\end{array}$ & $\begin{array}{l}\text { Fraction of complex is too small based } \\
\text { upon known CD and fluorescence } \\
\text { experiments. The fractions for PJun } \\
\text { monomer/dimer ratio are not in } \\
\text { agreement. }\end{array}$ \\
\hline 3 & $\begin{array}{l}40 \\
9.6 \\
4.8\end{array}$ & $\begin{array}{l}0.684 \\
0.201 \\
0.115\end{array}$ & $\begin{array}{l}\text { Best Fit and fractions of PJun are in } \\
\text { agreement to PJun monomer/dimer } \\
\text { ratio determined for PJun alone and } \\
\text { also in agreement with CD and } \\
\text { fluorescence data. }\end{array}$ \\
\hline 4 & $\begin{array}{l}30 \\
9.6 \\
4.8\end{array}$ & $\begin{array}{l}2.464 \\
0.037 \\
-1.501\end{array}$ & Fractions are nonsensical \\
\hline 5 & $\begin{array}{l}20 \\
9.6 \\
4.8 \\
\end{array}$ & $\begin{array}{l}1.113 \\
-0.087 \\
-0.026 \\
\end{array}$ & $\begin{array}{l}\text { Fractions are nonsensical and curve } \\
\text { fits and residuals do nit fit the data }\end{array}$ \\
\hline
\end{tabular}



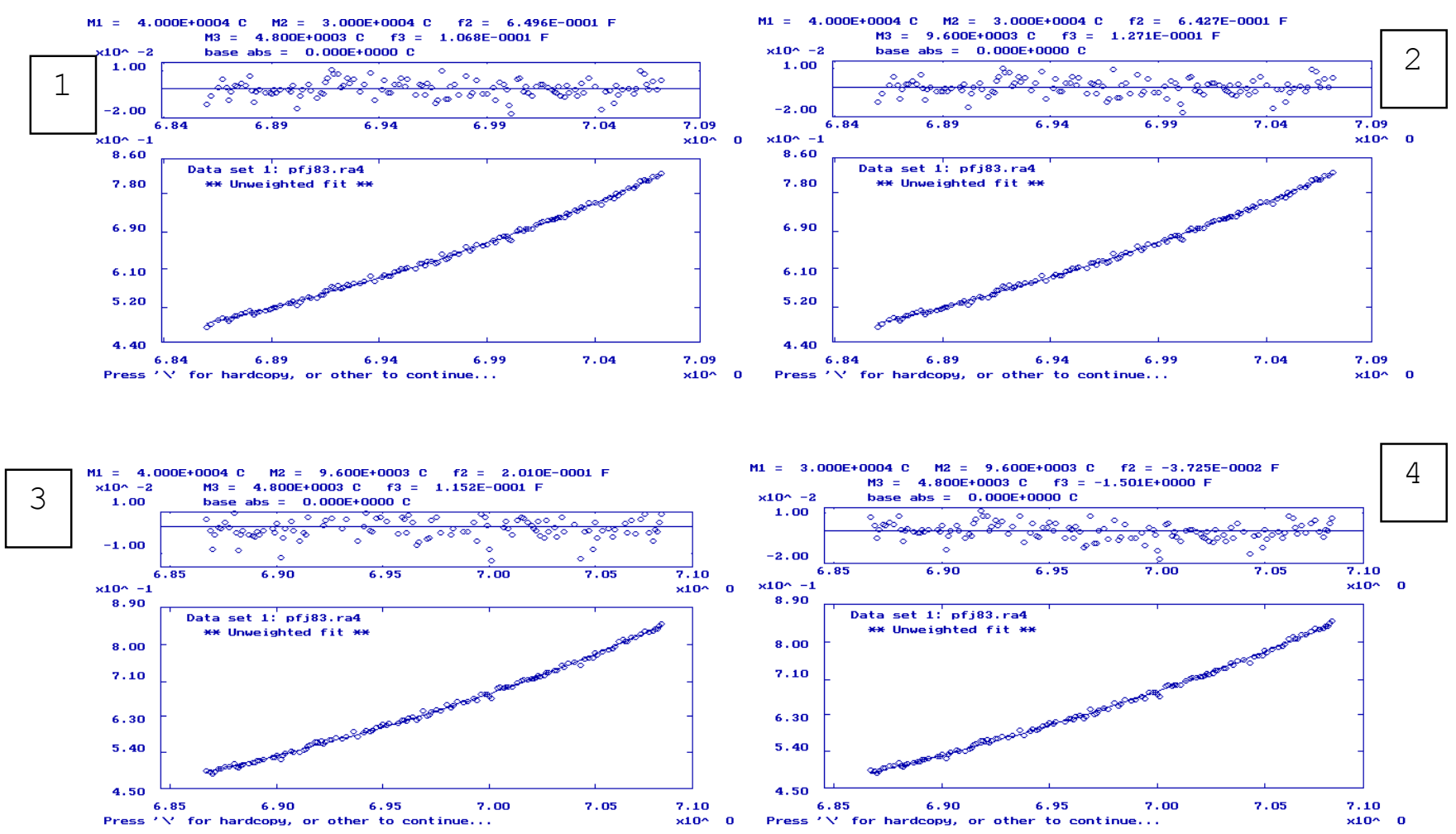

$M 1=2.000 E+0004 \mathrm{C} \quad \mathrm{M2}=9.600 \mathrm{E}+0003 \mathrm{C} \quad \mathrm{f2}=-8.661 \mathrm{E}-0002 \mathrm{~F}$

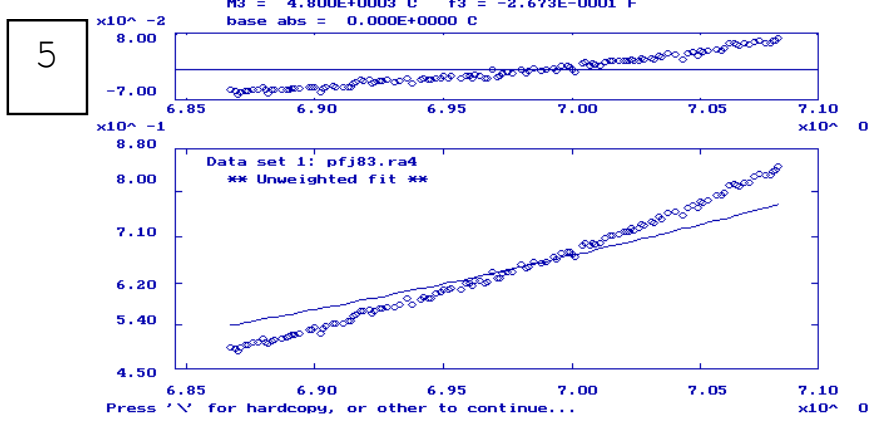

Figure S6. Sedimentation equilibrium data analysis of $\mathrm{D}_{0}$-Fos 4 mixed with 8 equivalents of PFos. Fits are shown for 1-5 as described in Table S2. 


\section{Unconstrained Fit for $\mathrm{P}_{\mathbf{0}} \mathrm{Fos}_{4} / 4 \mathrm{Jun}$}

Finally, we unconstrained the molecular weight of the assembled complex, and we also know there is excess PJun insolution, so PJun (MW $4.8 \mathrm{kD}$ ) and homodimer of 2.PJun (MW 9.6 kD) must show up in the solution as seen in $\mathrm{CD}$ and sedimentation equilibrium experiments. Thus we constrained these two molecular weight parameters. The resulting fit with this constraint showed a very good fit with evenly distributed residuals. The experimental MW of the assembled complex was found to be $41.56 \mathrm{kD}$, is in close agreement to the theoretical MW $(39.5 \mathrm{kD})$ of the complex $\mathrm{P}_{0} \mathrm{Fos}_{4} / 4 \mathrm{Jun}$.

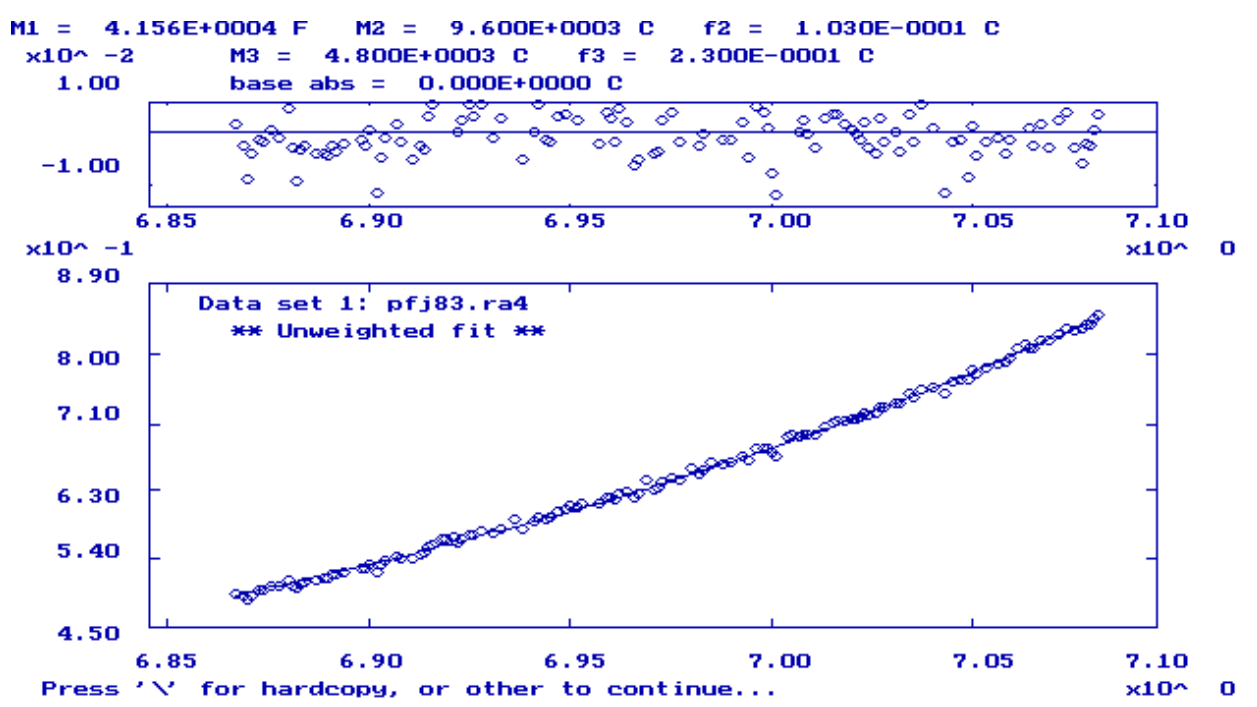

Figure S7. Unconstrained Fit for the sedimentation equilibrium data analysis of $\mathrm{D}_{0}-\mathrm{Fos}_{4}$ mixed with 8 equivalents of PFos 